\title{
Perubahan Muara Bodri Periode 1972-2017 Diinterpretasi pada Citra Landsat, dan Pengaruhnya Terhadap Pantai Kendal
}

\section{The Changing of Bodri Esturies 1972-2017 Periode Interpreted on Landsat Imageries, and the Influence on the Kendal Coastal}

\author{
Sidarto, Indra Sanjaya dan Jamal \\ Pusat Survei Geologi, Jalan Diponegoro No.57 Bandung \\ email: sidarto55@yahoo.com \\ Naskah diterima : 15 Oktober 2020, Revisi terakhir : 27 Oktober 2020 Disetujui : 02 November 2020, Online : 02 November 2020 \\ DOI: http://dx.doi.org/10.33332/jgsm.geologi.21.4.165-175p
}

\begin{abstract}
Abstrak-Dataran Kendal mempunyai peran sangat penting dalam transportasi di pantai utara Jawa Tengah, sehingga infrastruktur dan populasi daerah ini berkembang dengan cepat. Lima sungai utama mengalir di Dataran Kendal, yaitu Sungai Bodri, Sungai Cangkring, Sungai Blukar, Sungai Damar, dan Sungai Koto. Sungai Bodri mempunyai daerah aliran sungai (DAS) paling luas, dengan perkembangan sangat dinamis. Data penginderan jauh sangat efektif digunakan untuk monitoring permukaan bumi, baik lokal maupun regional. Untuk mengetahui perubahan Delta Bodri digunakan Citra Landsat, yang meliputi citra landsat Multispectral Scanner (MSS) tahun 1972, citra landsat Thematic Mapper (TM) tahun 1992, citra Landsat Enhance Thematic Mapper+ (ETM+) tahun 2001, dan citra Landsat Data Continuity Mission (LDCM) tahun 2017. Citra MSS dan TM dilakukan koreksi geometri, sedangkan citra lainnya sudah mempunyai titik kontrol secara otomatis. Pantai dan sungai diinterpretasi pada setiap citra di layar komputer, hasilnya ditumpang-tindihkan dan perbedaannya dianalisis secara ilmiah. Pada citra Landsat MSS, tampak Muara Bodri bercabang dua, yaitu Sungai Badri dan Sungai Kenceng, yang masing-masing membentuk delta cuspate. Penampakan citra Landsat TM menunjukkan Sungai Bodri sudah bermeander, dan muara sungai agak menjorok ke laut. Sementara itu, muara Sungai Bodri pada citra Landsat ETM+ menjorok ke baratlaut dan membentuk delta kerucut, sedangkan pada citra LDCM sungai ini berbelok ke utara, dan muara sungai menghadap relatif ke utara. Muara Sungai Badri warnanya makin pekat, yang ditunjukkan oleh warna putih pekat, mengidentifikasikan suplai material sungai bertambah. Sebaran pengendapan suspended material makin meluas, menunjukkan energi di laut makin besar. Perubahan Muara Bodri dipengaruhi oleh kondisi DAS Badri Hulu (batuannya mudah tererosi, dipicu oleh tutupan lahan terbuka dan curah hujan tinggi); dan energi laut berupa gelombang barat, yang dipengaruhi oleh pemanasan global.
\end{abstract}

\begin{abstract}
The Kendal coastal plain has a very important role in land transportation on the north coast of Central Java, so the infrastructures and populations are growing rapidly up. Five main rivers flow in the Kendal Plain, namely Bodri, Cangkring, Blukar, Damar, and Koto Rivers. The Bodri River has the most extensive watersheds, and is quite dynamic. Remote sensing data is very effective to be used for monitoring the earth surface, both locally and regionally. To find out the changing of Bodri Delta, Landsat imageries are utilized, involving Multispectral Scanner (MSS), 1972, Themathic Mapper(TM), 1992, Enhance Thematic Mapper $+($ ETM+), 2001, and Landsat Data Continuity Mission (LDCM), 2017 landsat imageries. The Landsat MSS and TM images are carried out geometric correction, while the other imageries have automatic control points. On the MSS Landsat imagery, the Bodri River has two branches, namely the Bodri and Kenceng Rivers, forming the cuspate deltas respectively. Landsat TM imagery shows the Bodri River has a meander pattern, and the river protrudes into the sea, forming cone delta. The Bodri River estuary on the ETM + landsat image shows to protrude to northwest and forms a cone delta, while on the LDCM imagery shows that the river turns to north, and the estuary faces relatively to the north. The estuary of the river is increasingly concentrated, which is shown by the colors, identifying the river's material supply is increasing. The distribution of suspended material is expanding, indicating greater energy in the sea. The changing of the Badri Estuaries are influenced by the condition of the Upstream Bodri Watershed (the rocks are easily eroded, triggered by bare land covers and high rainfall ), and the ocean energy originating from the western waves, affected by global warming.
\end{abstract}

Keywords: Badri Estuary, landsat emageries, 1972-2017 periode Kendal Costal growth. 


\section{PENDAHULUAN}

Dataran Kendal mempunyai peran sangat penting dalam transportasi darat di pantai utara Jawa Tengah, karena setiap transportasi darat dari Jawa Timur dan sebagian Jawa Tengah bagian timur ke Jakarta harus melewati dataran ini. Oleh karena itu, perkembangan infrastruktur dan penambahan populasi daerah ini berkembang dengan cepat. Perkembangan ini mengakibatkan perubahan morfologi sebagai dampak perubahan tataguna lahan, sehingga mengakibatkan peningkatan erosi dan polusi.

Ada lima sungai utama mengalir di Dataran Kendal, yaitu Sungai Bodri, Sungai Cangkring, Sungai Blukar, Sungai Damar, dan Sungai Koto. Di antara sungai-sungai tersebut, Sungai Bodri mempunyai daerah aliran sungai (DAS) paling luas, dan kondisi muaranya sering berubah. Sanjoto dkk. (2019) mengatakan bahwa Delta Bodri sangat dinamis, Bird dan Ongkosongo (1980) telah melakukan penelitian tentang perubahan Delta Bodri 1864-1973, dan Lumbanbatu (2009) telah menulis karya ilmiah bertopik perkembangan dataran pantai daerah Kendal.

Sebenarnya teknik penginderaan jauh sendiri merupakan disiplin ilmu yang relatif muda, namun teknologi ini telah meningkatkan kemampuan manusia dalam pemetaan, eksplorasi sumberdaya dan monitoring permukaan bumi, baik secara global maupun lokal (Rencz 1999; Lillesand dkk. 2015; Thenkabail 2015, dalam Gupta, 2018).

Landsat merupakan salah satu satelit penginderaan jauh milik Amerika Serikat. Sampai saat ini sudah delapan (8) generasi satelit secara berkesinambungan telah diluncurkan, dan sudah menghasilkan jutaan citra. Sebagian besar citra tersebut sudah banyak digunakan untuk berbagai penelitian. Beberapa keunggulan citra Landsat adalah (1) resolusi temporalnya baik, satelit ini mempunyai resolusi temporal 16, yang artinya satelit tersebut akan memotret daerah yang sama dalam waktu 16 hari, (2) resolusi spektralnya cukup baik, yaitu chanel biru, hijau, merah, inframerah dekat, dan inframerah sedang mempunyai resolusi $30 \mathrm{~m}$ (kecuali Landsat MSS dengan resolusi 80 $\mathrm{m}$ ), chanel pankromatik (band 8) mempunyai resolusi 15 $\mathrm{m}$, dan inframerah thermal beresolusi $60 \mathrm{~m}$, (3) dalam format digital, (4) citra yang dihasilkan mempunyai proyeksi orthogonal, (5) perolehan datanya relatif mudah dan gratis, (6) cakupan sangat luas (180 x $180 \mathrm{~km} 2)$.

Artikel ini akan membahas perubahan Muara Sungai Bodri 1972-2017 berdasarkan interpretasi citra Landsat, dan pengaruhnya terhadap Pantai Kendal.

\section{Lokasi}

Daerah penelitian berupa pedataran, termasuk wilayah Kabupaten Kendal, Propinsi Jawa Tengah. Wilayah ini merupakan jalur pantai utara (pantura) Jawa Tengah (Gambar 1).

\section{METODOLOGI}

Citra Landsat yang digunakan dalam penelitian ini terlihat pada Tabel 1 dan Gambar 2. Selain data citra Landsat tersebut, juga digunakan citra Digital Elevation Model (DEM) Terra-SAR X, yang direkam tahun 2012 dari Pusat Survei Geologi, dan citra SPOT 7 dari Lapan. Citra DEM digunakan untuk interpretasi geologi, dan citra SPOT digunakan untuk refisi dan validasi. Semua data dalam bentuk digital, sehingga dapat diolah sesuai kebutuhan.

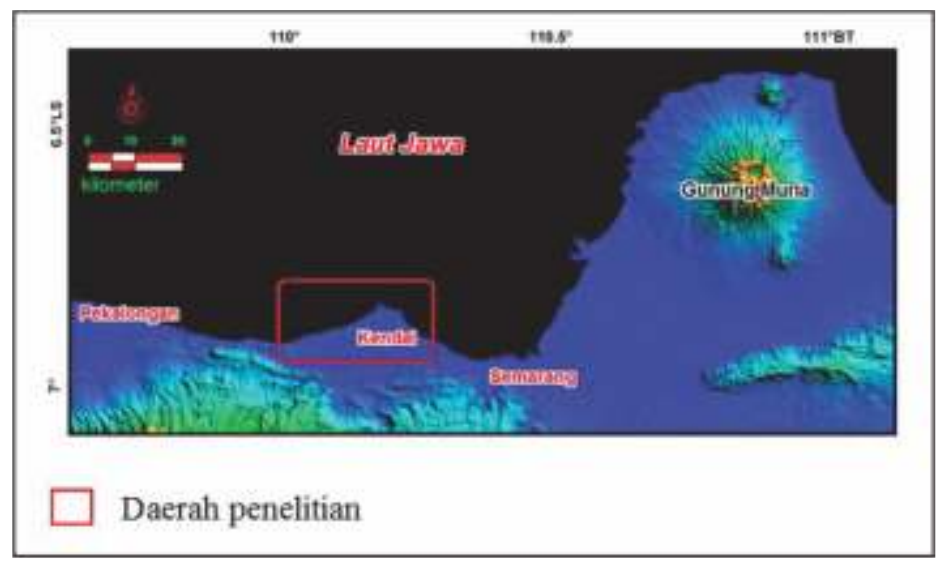

G ambar 1. Lokasi daerah penelitian di wilayah Kabupaten Kendal, Jawa Tengah. 
Tabel 1. Citra Landsat yang digunakan pada penelitian ini

\begin{tabular}{|c|c|c|c|c|}
\hline Citra Landaat & PathRow & dircàm & $\begin{array}{l}\text { Krexbibi } \\
\text { gocmutin }\end{array}$ & Kweliten citn \\
\hline $\begin{array}{l}\text { Anwhipetiral Scouwer } \\
\text { (asss) }\end{array}$ & $12 \mathrm{E} / 65$ & $\begin{array}{l}28 \quad \text { Sepnenber } \\
1972\end{array}$ & dilakiba & bagas \\
\hline $\begin{array}{l}\text { Dwroutive Isyper } \\
\text { (MM) }\end{array}$ & 12085 & 16 Juli two & dilakinkan & thapda \\
\hline $\begin{array}{l}\text { Enchaver Jhowate } \\
\text { Mepper (ETM) } 7\end{array}$ & 12089 & 8 Acril 2001 & motonatis & hapente \\
\hline 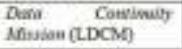 & 120665 & 4 agnil 2017 & Oormnis & Taga \\
\hline
\end{tabular}
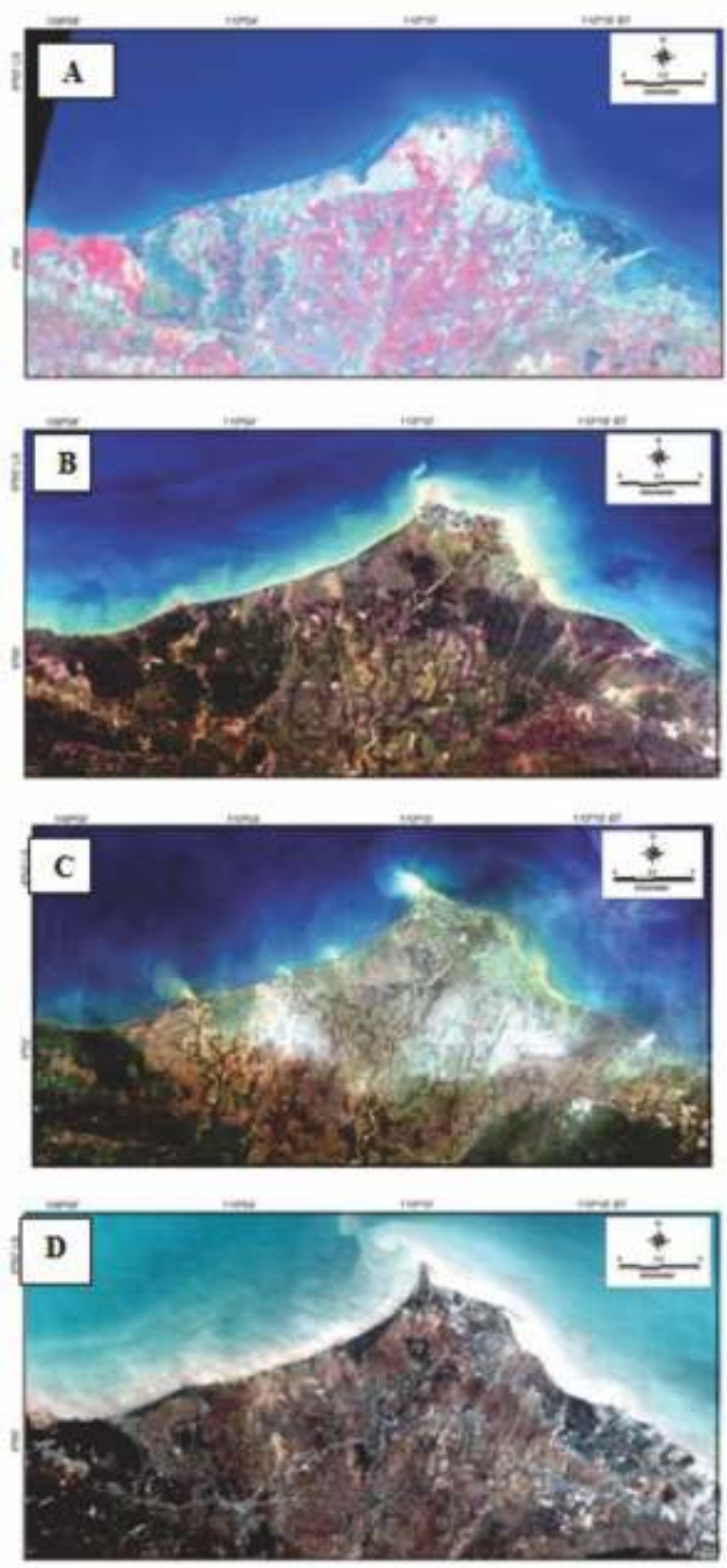

G ambar 2. Citra Landsatyang digunakan pada penelitian ini.. A: Citra LandsatMSS, RGB:4,3,1. (1972). B: CitraLandsatTM, RGB: 3,2,1(1992). C: Citra LandsatETM, RGB: 3,2,1(2001). D:Citra LandsatLDCM, RGB: 3,2,1(2017).
Koreksi geometri pertama yang dilakukan adalah Landsat TM dengan referensi Landsat ETM, karena resolusi spasial kedua citra sama $(30 \mathrm{~m})$, dan waktu rekaman kedua citra paling dekat. Hasil koreksi terdiri atas sebaran lokasi dan nilai kesalahannya (Gambar 3 dan Tabel 2). Koreksi geometri citra Landat MSS dengan menggunakan citra Landsat TM yang sudah dikoreksi, karena rekaman citra Landsat TM paling dekat dengan citra Landsat MSS, yang perubahannya paling sedikit. Oleh karena resolusi spasial kedua citra sangat berbeda, Landsat MSS mempunyai resolusi $80 \mathrm{~m}$ dan landsat TM $30 \mathrm{~m}$, mengakibatkan koreksinya sedikit mengalami kesulitan. Sebaran titik koreksi dan kesalahannya dapat dilihat pada Gambar 4 dan Tabel 3.

Setelah citra dikoreksi, interpretasi muara Sungai Bodri dilakukan pada masing-masing citra secara semi manual pada layar komputer (monitor). Agar penampakan proses-proses di pantai dapat kelihatan, maka dipilih kombinasi RGB chanel 4, 3, 1 untuk Landsat MSS, dan citra lainnya menggunakan kombinasi RGB 3,2, 1 .

Selanjutmya, dilakukan interpretasi pantai dan sungai di daerah Kendal dan sekitarnya. Hasil interpretasi ditumpang-tindihkan sehingga diketahui perubahan dan perkembangannya. Validasi dilakukan pada citra SPOT yang lebih rinci, dan citra DEM digunakan untuk interpretasi geologi DAS Bodri bagian hulu.

\section{PERUBAHAN MARA SUNGAI BODRI DAN PENGARUHNYA TERHADAP PANTAI KENDAL}

Endapan sedimen yang berasal dari daratan (sungai) diendapkan pada tubuh air tenang (laut atau danau) disebut delta (Setiyono, 1996). Perkembangan delta dikontrol oleh pasokan material dan aktivitas di wilayah pengendapan. Reineck dan Singh (1973) menyatakan bahwa bentuk delta dikontrol oleh morfologi pesisir, arah dan intensitas gelombang, tingkat pengangkutan sedimen, serta pasang surut. Faktor-faktor tersebut mempunyai pengaruh berbeda-beda, sehingga membentuk berbagai macam tipe delta.

Sebelum tahun 1972 kondisi Muara Sungai Bodri diinterpretasi pada peta topografi Lembar Semarang skala 1:100.000, yang dibuat oleh Seksi Kartografi, Direktorat Geologi berdasarkan kompilasi US Army map service skala 1:50.000, tahun 1965. Berdasarkan peta tersebut pada 1965, Sungai Bodri bercabang dua, yaitu Sungai Bodri dan Sungai Kenceng (Gambar 5). Sungai Bodri mengalir ke arah utara-baratlaut dan muaranya membentuk delta tumpul (bentuknya seperti busur), yang berkembang di Tanjung Karawelang. Bentuk delta ini menandakan bahwa gelombang laut cukup kuat dan tegak lurus terhadap pantai, sehingga material disebarkan secara merata ke arah kiri dan kanan muara sungai. 
Sungai Kenceng mengalir ke arah timurlaut dengan cabang Sungai Jakan yang mengalir ke utara. Secara keseluruan Muara Sungai Kenceng membentuk delta lobben (seperti kaki burung), mencerminkan material yang dibawa sungai banyak, dorongan air sungai besar, dan disebarkan ke segala arah, sedangkan tahanan dari massa air laut tidak ada. Muara Sungai Kenceng dilindungi oleh tubuh dataran, sehingga angin barat hampir tidak berpengaruh, dan delta berkembang dengan baik. Perkembangan Muara Bodri pada tahun 1965 hanya sebagai pembanding hasil interpretasi citra 1972 pada artikel ini.

Pada citra Landsat MSS, yang direkam tahun 1972, Muara Sungai Bodri mengalir ke baratlaut dengan muara sungai menghadap relatif ke utara.

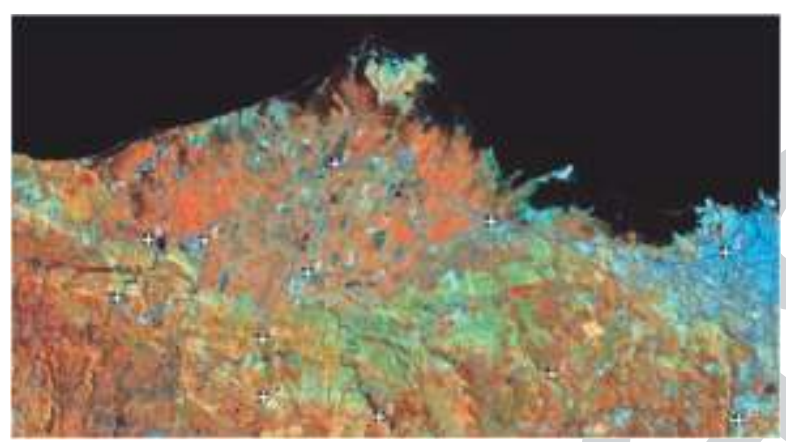

G ambar 3. Sebaran Ground Control Points (GCP) pada citra Landsat TM, sebelumrectify.

Tabel 2. Koordinat GSP dan kesalahan atau R oot M ean Square(RMS) pada LandsatTM

\begin{tabular}{|c|c|c|c|c|c|c|c|c|c|}
\hline Nane & On & Edet & Undo & $\cos x$ & CedY $Y$ & Eating & Nothing & Heght: & AMS \\
\hline t & on & Edt & & 128594 & 551.69 & $412 \cos 3 \pi$ & $9230466.51 \mathrm{~W}$ & 000 & 0.41 \\
\hline 2 & on & Edat & & 9034 & 41569 & 406917 TDE & 9234316 PSN & 000 & 104 \\
\hline 3 & on & Edet & & 1855.45 & 52456 & $43400555 E$ & S2204165iN & 000 & 124 \\
\hline 4 & on & Eder. & & 837.39 & 57257 & $\triangle 05042$ \&3E & $222700535 \mathrm{~N}$ & 0,00 & $\theta B$ \\
\hline 5 & On & Eat & & 58740 & $5 \% 51$ & 397965 58E & $922921904 \mathrm{~N}$ & 000 & 0.50 \\
\hline 6 & on & Ed & & 44756 & 5935 & $3939572 \pi$ & $922930423 \mathrm{~N}$ & 000 & 0.45 \\
\hline 7 & on & Ede & & 143353 & 90959 & $42205301 \mathrm{E}$ & $9220294 \times 0 \mathrm{~N}$ & 0,00 & 022 \\
\hline 8 & on & Edt & & 101260 & 100595 & $41008520 E$ & $92174454 \mathrm{iN}$ & 000 & 0.14 \\
\hline 9 & on & Ede & & 7265 & 22847 & $40190728 E$ & $9222539.17 \mathrm{~N}$ & 000 & $0 \pi$ \\
\hline 10 & on & Edt & & 37205 & 73237 & $39181124 \mathrm{E}$ & $9225347 \mathrm{eON}$ & 0,0 & 0.09 \\
\hline 11 & on & Edt & & $1825,4:$ & 1018.42 & $435021.51 E$ & $921718939 \mathrm{~N}$ & 0,0 & Q.6? \\
\hline 12 & on & Ese & & 700.9 & 96367 & A0202S 4AE & $92197572 \mathrm{NN}$ & 000. & 0.5 \\
\hline
\end{tabular}

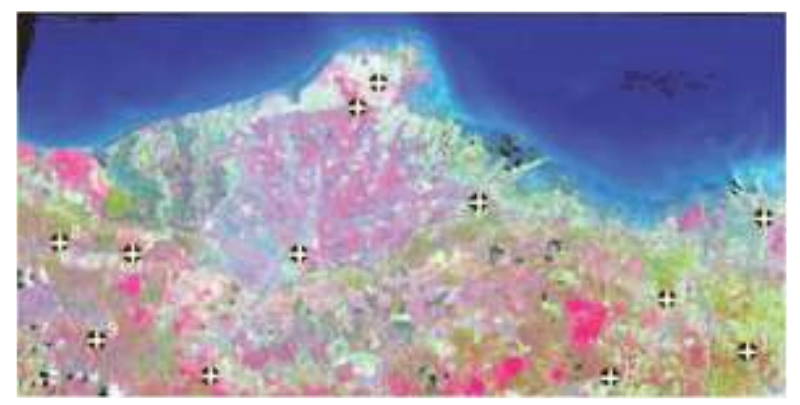

Gambar 4. Sebaran Ground Control Points (GCP) pada Landsat MSS sebelum rectify.
Tabel 3. Koordinat GSP dan kesalahan atau Root Mean Square (RMS) pada Landsat MSS

\begin{tabular}{|c|c|c|c|c|c|c|c|c|c|}
\hline Name & On & Edx & Undo. & Cel X & CetY & Easting & Northing & Height & AMS \\
\hline 1 & On & Ede & & 1056.35 & 69280 & 437328806 & $.780034 .59 \mathrm{~N}$ & 0.00 & 165 \\
\hline 2 & On & Ed & & 561.26 & 37660 & $409194.71 E$ & $-762524 \mathrm{cSN}$ & 0.00 & 133 \\
\hline 3 & On & Edt & & 588.62 & 34585 & $410775.42 E$ & $.760778 .92 \mathrm{~N}$ & 0.00 & 1.11 \\
\hline 4 & On & Ecte & & 488.94 & 55979 & 405033515 & $77300095 \mathrm{~N}$ & 000 & 102 \\
\hline 5 & on & Eda & & 375.26 & 71360 & $399473.13 E$ & $.78200515 \mathrm{~N}$ & 000 & 293 \\
\hline 6 & on & Edt & & 71523 & 494.41 & $41704984 E$ & $-76957576 \mathrm{~N}$ & 0,00 & 451 \\
\hline 7 & On & Ede & & 27846 & 560.16 & 393059.538 & $77303554 \mathrm{~N}$ & 0.00 & 0.70 \\
\hline 8 & On & Edt & & 185.89 & 54652 & $38795720 \mathrm{CE}$ & $77234196 \mathrm{~N}$ & 0.00 & 313 \\
\hline 9 & On & Edk & & 233.36 & 66501 & $39031971 E$ & $-77910539 \mathrm{~N}$ & 000 & 303 \\
\hline 10 & On & Edt & & 1075.69 & 51471 & $436501.80 E$ & $-77057299 \mathrm{~N}$ & 0.00 & 1.52 \\
\hline 11 & On & Edt & & 953.18 & 617.74 & $43133926 \mathrm{E}$ & $-77633445 \mathrm{~N}$ & 0.00 & 1.75 \\
\hline 12 & On & Ed & & 881.72 & 71454 & $42734886 E$ & $78187927 \mathrm{~N}$ & 0.00 & 1.15 \\
\hline
\end{tabular}

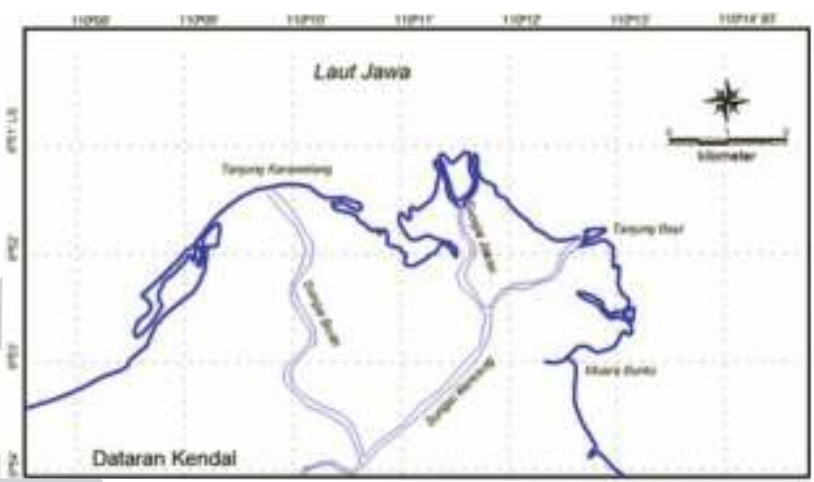

G ambar 5. Muara Sungai Bodri tahun 1965 (berdasarkan sebagian dari peta topografi Lembar Semarang, skala 1:100.000).

Berdasarkan pemboran dangkal (Poedjojitno dkk., 2009), Sungai Bodri sebelum 1972 sudah tidak aktif, sementara itu Sungai Kenceng mengalir ke arah timurlaut. Di Muara Sungai Bodri terbentuk delta cuspate, demikian juga Sungai Kenceng secara keseluruhan juga membentuk delta cuspate, yang menunjukkan adanya keseimbangan energi sungai dan tenaga laut. Garis pantai Muara Sungai Bodri mengalami penambahan cukup signifikan ke arah timurlaut dibanding garis pantai 1965 (Gambar 6). Hal ini sesuai dengan hasil penelitian Bird dan Ongkosongo (1980) bahwa perubahan pantai Delta Bodri tahun 1864-1973 bertambah ke arah timurlaut, dan juga material yang dibawa oleh Sungai Kenceng jauh lebih besar daripada Sungai Bodri sendiri (Lumbanbatu, 2009). Delta Bodri sendiri lebih kecil daripada Delta Kenceng, mungkin disebabkan oleh energi gelombang dari barat lebih besar, sehingga penambahan ke arah timurlaut lebih signifikan. Sementara itu, Tanjung Karawaleng terabrasi, dan materialnya terbawa ke arah selatan. Secara umum pantai barat terjadi pemeratan, sehingga pantai lurus, sementara itu pantai timur mengalami penambahan. Delta Cangkring dan seluruh pantai ke tenggara berkembang baik (Gambar 7). Penambahan ini mungkin pantai timur tidak terpengaruh arus barat, karena terhalang tubuh Dataran Kendal. 


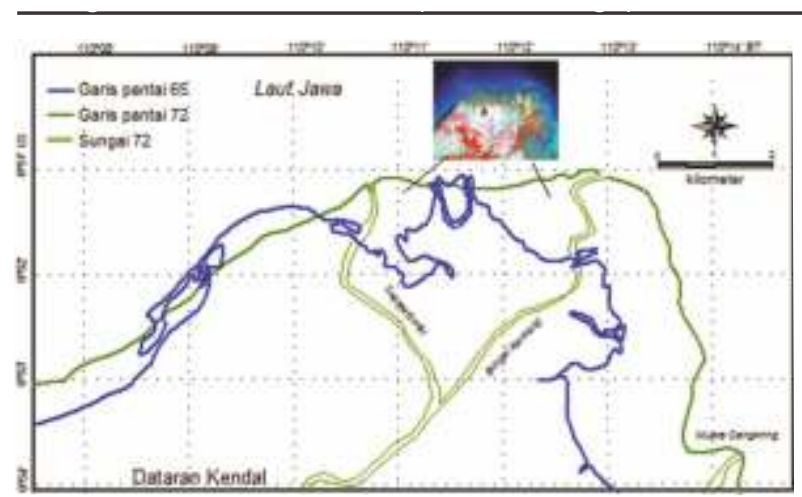

Gambar 6. Perubahan Muara Sungai Bodri tahun 1965 sampai tahun 1972.

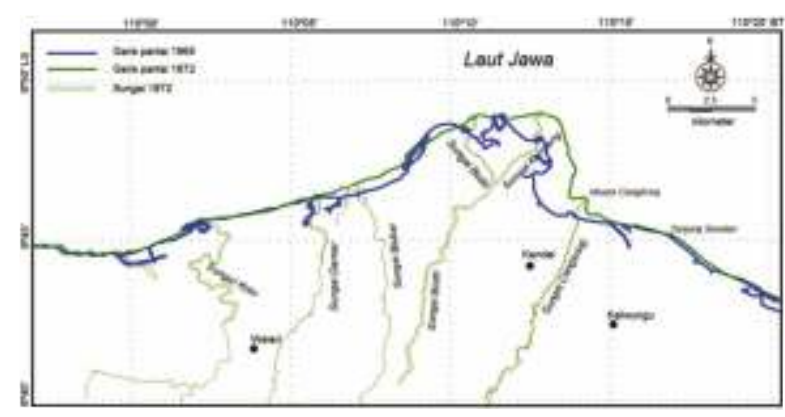

G ambar 7. Perubahan Pantai Kendal tahun 1965 sampai tahun 1972.

Pada citra Landsat TM tahun 1992, Sungai Kenceng sudah tidak aktif lagi, yang disebabkan oleh limpasan sungai besar (Sanjoto dkk., 2017), dan satu-satunya sungai aktif adalah Sungai Badri. Di bagian muara, sungai ini sudah berbelok-belok (sungai bermeander) ke arah barat, dan kemudian berbelok ke utara, dengan muara sungai menghadap ke utara-baratlaut.

Delta Bodri mengalami penambahan, membentuk delta cuspate lebih besar daripada sebelumnya dan menjorok ke laut. Di bagian muara Sungai Badri menunjukkan warna putih, yang berarti banyak material sampai ke laut, dan materialnya disebarkan ke timur oleh gelombang laut (Gambar 2B). Peta Rupa Bumi Indonesia (RBI) yang dibuat oleh Bakosurtanal (sekarang Badan Informasi Geospasial) sama dengan bentuk ini, karena peta tersebut dibuat berdasarkan potret udara tahun 1991. Di pantai timur sudah tidak terlindung lagi oleh tubuh delta, gelombang barat menabrak pantai, sehingga terjadi abrasi cukup besar, namun Delta Cangkring masih mengalami penambahan. Tanjung Siwalan bagian utara mengalami abrasi, sedangkan di selatan terjadi penambahan, dan Pelabuhan Kendal di Merbuh telah dibangun (Gambar 8). Di pantai barat bagian utara dekat dengan Muara Bodri mengalami abrasi dan materialnya diendapkan kembali di pantai bagian selatannya, sehingga pantai barat menunjukkan garis lurus (Gambar 9).
Citra Landsat ETM yang direkam tahun 2001 memperlihatkan bahwa bagian Muara Sungai Badri mengalami perpindahan dan sungai menjorok ke laut. Muara sungai menghadap ke utara-baratlaut dan materialnya dihamburkan ke baratlaut, kemudian disebarkan ke segala arah, dan lebih luas daripada tahun 1992. Delta yang terjadi berbentuk kerucut, menyempit ke arah ujungnya. Hal ini menandakan bahwa energi sungai mengecil, dan pantai landai, material meningkat (Gambar 10). Sebenarnya arus sungai tidak mengecil tetapi arusnya ditahan oleh energi laut yang bertambah besar.

Dibandingkan dengan pantai 1992, pantai barat di bagian utara yang dekat muara sedikit mengalami penambahan, dan pantai barat ini terlihat lurus. Setiap sungai yang bermuara di pantai barat menunjukkan arusnya terbawa ke baratdaya. Sungai Blukar yang pada citra TM 92 menunjukkan pola bermeander, yang mungkin sering menimbulkan banjir. Pada tahun 2001 sungai ini telah diluruskan dan pantainya mengalami sedikit penambahan. Di kampung nelayan sedang dibuat suatu bagunan, sementara itu Muara Sungai Damar dan Sungai Koto mengalami penambahan. Sementara itu, di bagian timur gelombang mampu mendorong material pantai ke arah timur, dan membentuk punggungan (Gambar 11). Di sebelah selatan punggungan ini terbentuk suatu teluk dengan situasi tenang, karena terlindungi oleh punggungan tersebut. Delta Cangkring terus tumbuh, menunjukkan material yang dibawa sungai cukup besar, kerena banyak terdapat penambangan golongan $\mathrm{C}$ di dalam DAS Cangkring dan arus sungai cukup besar, sementara itu energi laut lemah, yang dilindungi oleh punggungan. Tanjung Siwalan ke selatan sedikit mengalami abrasi.

Penampakan pada citra LDCM yang direkam pada tahun 2017 menunjukkan Muara Sungai Bodri membelok ke utara, dan mengalir di sebelah timur sungai tahun 2001, menjorok jauh ke laut, dan muaranyanya menghadap ke utara, serta menyemburkan material ke segala arah (Gambar 12). Delta yang terjadi berbentuk kerucut, menandakan energi sungai menurun ke arah utara, dangkal, suplai material sungai bertambah, dan energi laut bertambah. Di pantai barat arah arus ke baratlaut sejajar pantai, yang merupakan hasil arus barat, dan dibelokkan oleh tubuh Delta Bodri. Di Muara Sungai Belukar setelah diluruskan membentuk delta, juga di Muara Damar membentuk delta kecil, sementara Muara Sungai Koto dibangun sedemikian rupa, sehingga muaranya lurus ke baratlaut. Suatu bangunan di kampung nelayan sudah selesai dibuat, namun di dalam pelabuhan airnya keruh dan membuat pendangkalannya cepat. Di pantai timur, material sungai disebarkan sepanjang pantai oleh gelombang barat, dan sayap timur 
Delta Bodri tererosi, punggungan yang terlihat pada citra ETM 2001 diabrasi dan tergeserkan ke selatan menjadi lebih kecil. Muara Cangkring bertambah sedikit. Di Tanjung Siwalan telah didirikan suatu bangunan, di dalamnya terlihat airnya keruh dan mengandung banyak suspended material, yang mungkin menyebabkan pendangkalan. Namun bangunan ini dapat berfungsi menahan suspended material, sehingga tidak mengganggu Pelabuhan Kendal di Merbun dan suspended material tidak menyebar sampai Semarang (Gambar 13).

Menurut Sanjoto dkk. (2018) bahwa Delta Bodri sangat dinamis perubahannya, ada proses abrasi dan penambahan di sepanjang pantai. Berdasarkan perubahan arah garis pantai dari Delta Bodri menunjukkan persamaan linier $\mathrm{y}=0,9553 \mathrm{x}+2014,8$ dengan nilai determinan $\mathrm{R} 2=0,1934$, dan telah menghitung luasan daratannya (Tabel4).

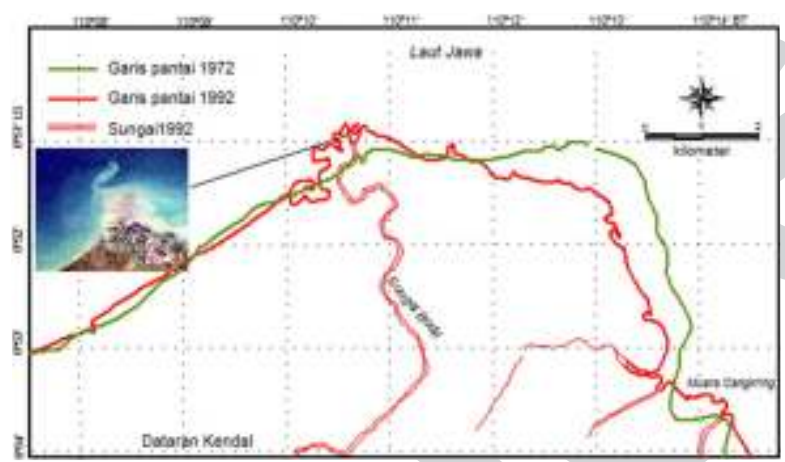

G ambar 8. Perubahan Muara Bodri antaratahun 1972sampai tahun 1992.

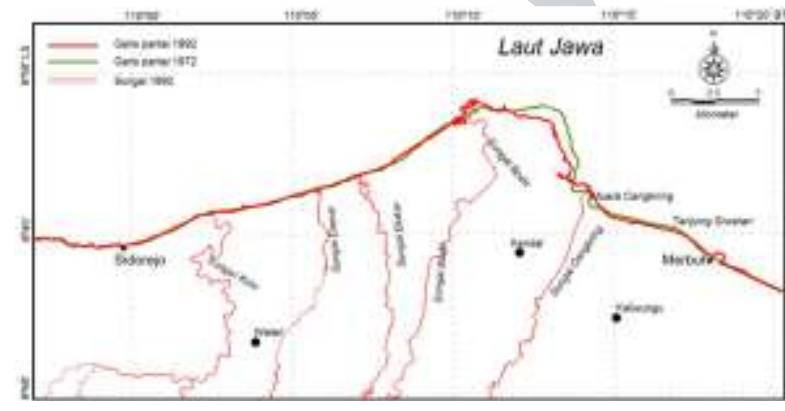

G ambar 9. Perubahan Pantai Kendal tahun 1972 sampai tahun 1992.

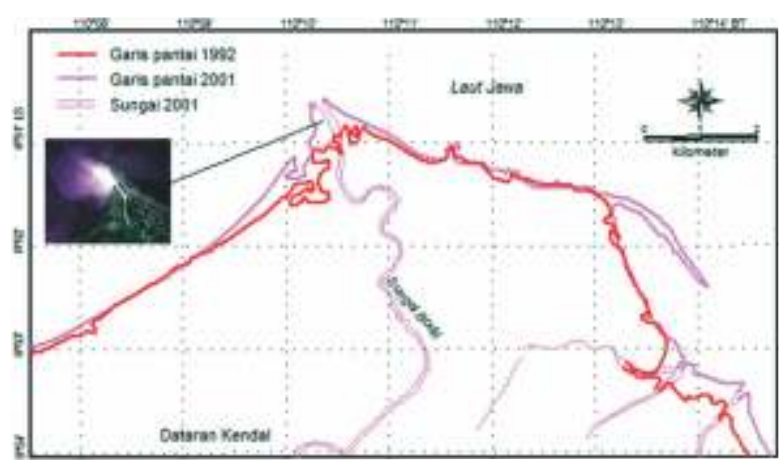

G ambar 10. Perubahan Muara Bodri antara tahun 1992 dan 2001.

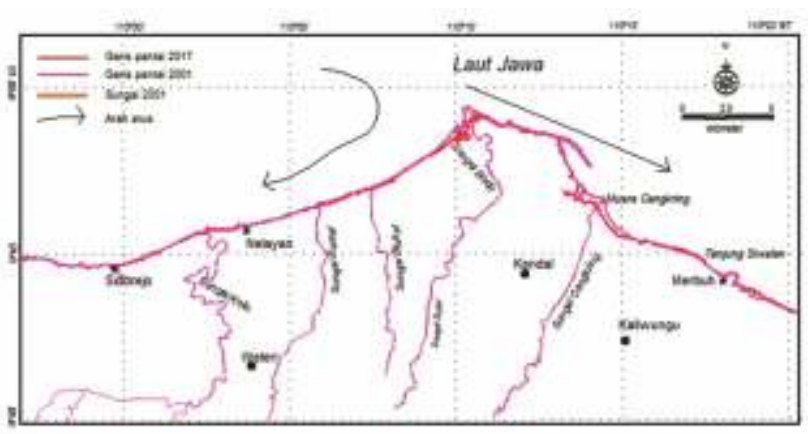

G ambar 11. Perubahan Pantai Kendal tahun 1992 sampai tahun 2001.

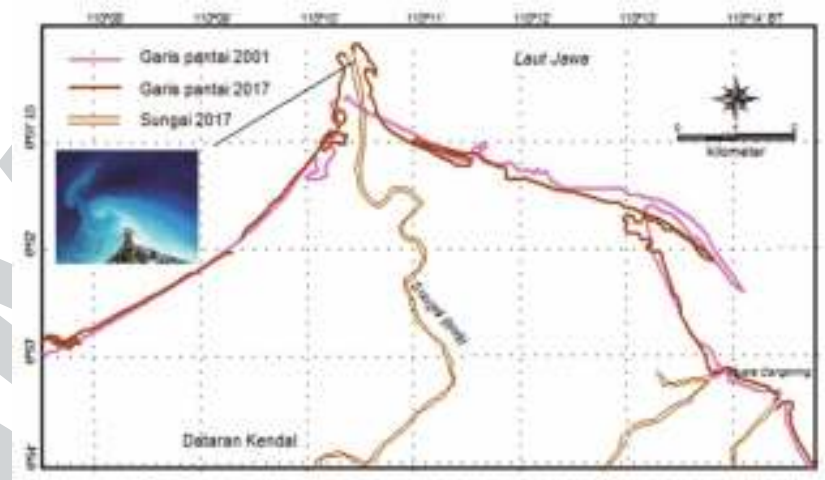

G ambar 12. Perubahan Muara Sungai Bodri antara tahun 2001 dan tahun 2017.

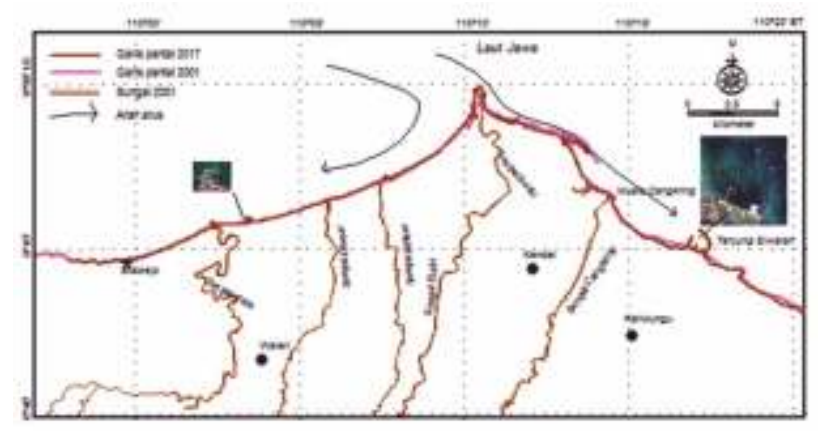

G ambar 13. Perubahan Pantai Kendal tahun 2001 sampai tahun 2017.

Tabel 4. Luasan Delta Bodri (Berdasarkan beberapa analisis, dalam Sanjoto dkk., 2018)

\begin{tabular}{|l|l|l|}
\hline Nomor & Tahum & Laas (ha) \\
\hline 1 & 1992 & 3915,591 \\
\hline 2 & 1997 & 3928,774 \\
\hline 3 & 2002 & 3907,201 \\
\hline 4 & 2007 & 3941,942 \\
\hline 5 & 2012 & 3963,432 \\
\hline 6 & 2017 & 3921,283 \\
\hline
\end{tabular}

\section{DISKUSI}

Muara Sungai Bodri periode 1972 sampai 2017 telah mengalami perubahan tiga kali, dan semakin menjorok ke laut, yang disebabkan oleh kondisi DAS Bodri Hulu dan energi laut. 


\section{Geologi DAS Bodri Hulu}

Secara fisiografi daerah penelitian termasuk Dataran Aluvial Jawa Utara (van Bemmelen, 1949). Namun DAS Bodri mempunyai wilayah sangat luas, yang meliputi Dataran Aluvial Jawa Utara, Zona BogorSerayu Utara-Kendeng, dan Zona Gunungapi Kuarter. Peta geologi DAS Badri Hulu (Gambar 14) dibuat berdasarkan interpretasi geologi citra DSM TerraSar$\mathrm{X}$ yang dikorelasikan dengan peta gelogi lembar Semarang-Magelang (Thenden dkk., 1996) dan peta geologi lembar Banjarnegara dan Pekalongan (Condon dkk., 1996), skala 100.000. Batuan tertua di daerah ini adalah Formasi Kerek (Nmk), yang tersusun oleh perselingan batulempung, batupasir tufan, konglomerat, breksi gunung api dan sisipan batugamping, yang berumur Miosen Atas (Thenden dkk.,1996), namun berdasarkan analisis foraminifera plangtonik di daerah Klantung, Kendal berumur Pliosen Akhir-Plistosen, sehingga sebagai Formasi Kalibeng (Sulastya Putra dan Praptisih, 2017). Satuan batuan ini menyebar hanya setempat saja. Batuan Gunung api Ungaran Purba (Ppvu) menindih secara tidak selaras Formasi Kerek. Batuan penyusunnya terdiri atas batuan gunung api (lava, breksi dan tuf), dan membentuk lingkaran yang mengelilingi Gunung api Ungaran, sehingga disebut sebagai Batuan Gunung api Ungaran Purba. Menindih tidak selaras di atas Batuan Gunung api Ungaran Purba ini adalah Formasi Damar, yang tersusun oleh batupasir tufan, konglomerat, breksi laharik. Formasi ini diduga hasil rombakan dari Batuan Ungaran Purba. Batuan Gunung api Ungaran Tua (Qvu) tersingkap hanya sedikit di bagian tenggara, pada peta geologi lembar Semarang-Magelang tidak disebut batuan gunung api apa, hanya simbol saja Qhg. Di bagian tenggara Batuan Gunung api Ungaran Muda (Qhvu) dan Batuan Gunung api Kaligesik (Qhvk) muncul di dalam Kawah Gunung api Ungaran Tua, sementara itu di baratlaut terdiri atas Batuan Gunung api Komplek Dieng (Qvd) dan Gunung api Ilerep (Qhvi). Di ujung Batuan Gunung api Ungaran Tua (Qvu) dan Batuan Gunung api Ungaran Muda (Qhvu) terdapat Endapan kipas aluvium (Qfa) dan di lembah Sungai Bodri terdapan endapan sungai (Qr). Struktur geologi yang berkembang adalah lapisan batuan dan antiklin, serta escarment.

Telah diuraikan di atas, batuan tertua terdiri atas batuan sedimen Miosen Atas (Formasi Kerek) yang secara fisik mudah mengalami erosi. Di dalam formasi ini juga dijumpai escarment cukup besar, yang menandakan adanya tanah longsor. Batuan Gunung api yang relatif masih muda dengan lereng terjal sangat mudah longsor, terlapukkan dan kemudian tererosi. Penampakan ini diperlihatkan oleh lereng terjal, bentuk lembah sungai dalam dan sempit, yang menunjukkan erosi vertikal aktif. Batuan Gunung api Ungaran Purba membentuk pola aliran rapat (Gambar 14), menunjukkan air hujan yang jatuh dialirkan sebagai aliran permukaan (run off).

Perubahan tata guna lahan diperlihatkan oleh hasil klasifikasi citra Landsat MSS (1973) dan citra Landsat LDCM (2017). Pada citra Landsat MSS tahun 1972 tidak mencakup DAS Badri Hulu, maka digunakan citra Landsat MSS 1973 (Gambar 15A). Pada citra tahun 1973 hampir tidak dijumpai lahan terbuka (Gambar 16A), namun pada citra LDCM 2017 (Gambar 15B), hasil klasifikasinya lahan terbuka mencapai lebih dari $30 \%$ (Gambar 16B), yang terutama berasal dari perubahan tumbuhan tipis/hutan, dan disebabkan oleh aktifitas manusia. Perubahan tata guna lahan ini meningkatkan erosi, yang memperbesar asupan material Sungai Bodri.

DAS Bodri Hulu, secara administrasi termasuk ke dalam wilayah Kabupaten Kendal dan Kabupaten Temanggung. Di Kabupaten Kendal mempunyai curah hujan lebih dari $2000 \mathrm{~mm}$ (Wikipedia, 2020), sedangkan di Kabupaten Temanggung termasuk Kecamatan Bejen dan Tretep menunjukkan curah hujan sedang, tinggi dan sangat tinggi (BPD Temanggung, 2019). Tingginya curah hujan ini membuat gerakan tanah, erosi dan arus sungai sangat besar, sehingga material yang dibawa oleh sungai besar dan energi sungai kuat.

\section{Energi laut}

Pada citra Landsat MSS (1972) suspended material di mulut sungai terlihat sedikit, namun suplai material sungai mengalami penambahan. Sepanjang pantai tidak ada abrasi, kecuali Tanjung Karawelang terabrasi dan materialnya digeser ke pantai baratlautnya. Pada citra

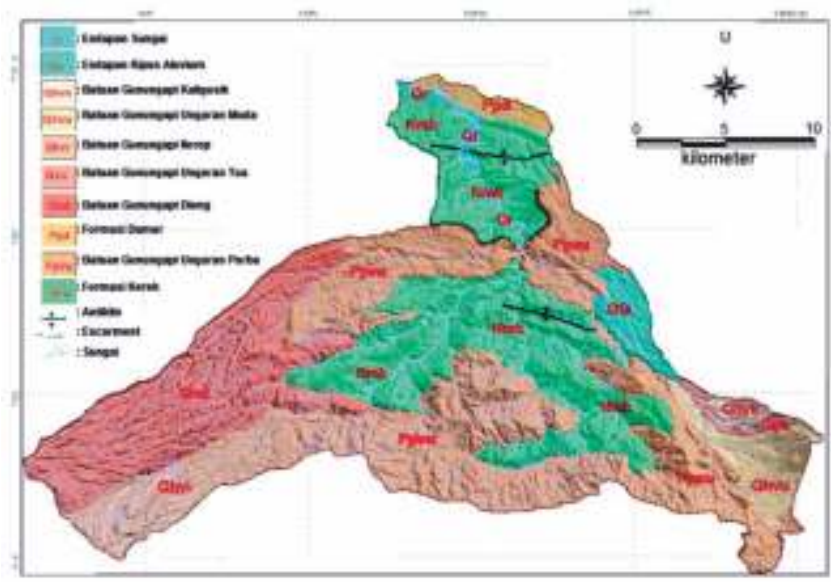

G ambar 14. Peta Geologi DAS Bodri Hulu diinterpretasi pada citra DEM . 


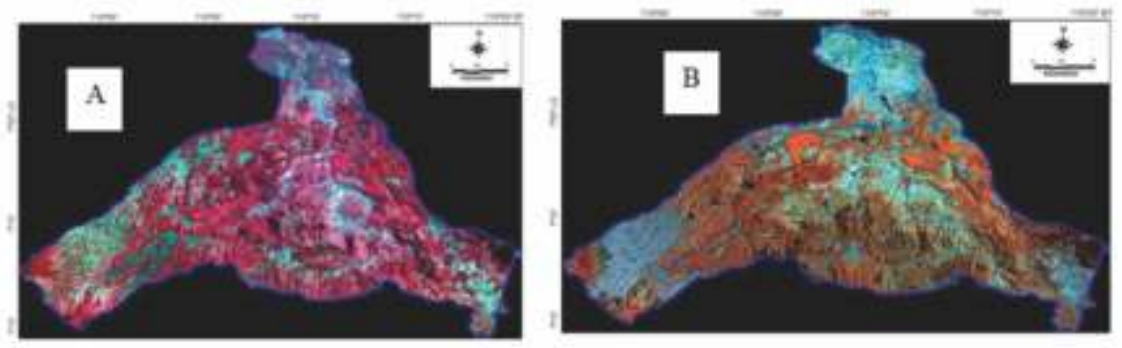

G ambar 15. Citra Lndsat DAS Bodri Hulu

A: Citra Landsat MSS (1973), B: Citra Landsat LDCM (2017).
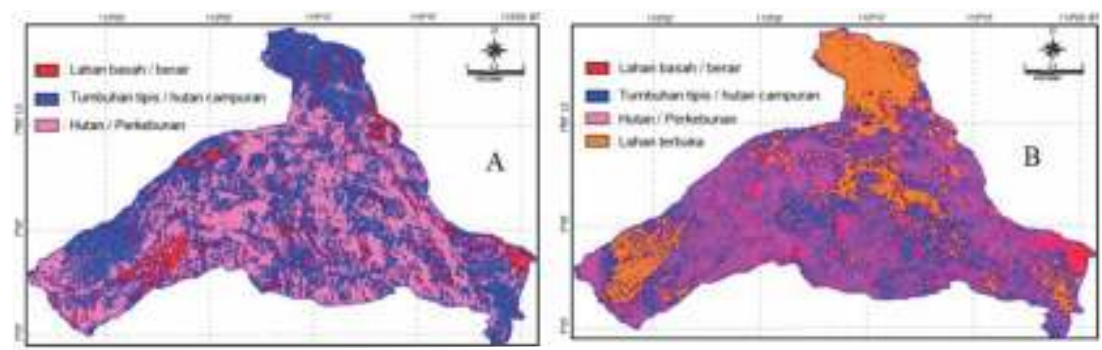

G ambar 16. Klasifikasi citra untuk tutupan lahan DAS Bodri Hulu.

A: Klasifikasi Citra Landsat MSS (1973), B : Klasifikasi Citra Landsat LDCM (2017).

Landsat TM (Gambar 2B), suspended material di muara sungai cukup tebal, yang menunjukkan ada penambahan suplai material, dan gelombang air laut membesar yang ditunjukan sebaran suspended material meluas, dan terjadinya abrasi di pantai timur Muara Sungai Bodri. Penampakan citra ETM (Gambar 2C) suspended material di muara sungai makin pekat, dan disebarkan secara luas, dan sebagian diendapkan sepanjang pantai timur di bagian utara, yang membentuk teluk. Sementara itu pada citra LDCM (Gambar 2D), delta menjorok ke utara, material disebarkan lebih luas. Berdasarkan penampakan pada citra dari tahun 1972 sampai 2017 gelombang laut dapat diprediksi terutama berasal dari barat.

\section{Angin Muson}

Kepulauan Indonesia terletak antara dua benua, yaitu Benua Asia dan Benua Australia, dan antara dua samudra, yaitu Samudra Hindia dan Samudra Pasifik, serta dilalui garis khatulistiwa. Dengan kedudukan tersebut, wilayah Indonesia dilalui oleh angin muson. Angin ini berhembus secara periodik. Antara periode yang satu dengan yang lain polanya saling berlawanan dan berganti arah secara berlawanan setiap setengah tahun (Gischa, 2020). Angin ini menjadi angin musiman yang bersifat periodik dan pada umumnya terjadi di Samudera Hindia dan Asia. Angin ini mirip dengan angin laut, namun memiliki skala lebih kuat dan lebih konstan. Fenomena muson dapat terlihat pada siklus cuaca tahunan di benua Asia, Australia, dan Afrika yang memiliki iklim tropis dan subtropis dengan siklus cuaca ekstrim. Pada prinsipnya ada dua muson, yaitu Angin Muson Barat, dan Angin Muson Timur.

\section{Angin Muson Barat}

Angin Muson Barat bertiup pada Oktober-April, matahari berada di belahan bumi selatan, yang menyebabkan Australia musim panas, dan bertekanan minimum, sedangkan Asia lebih dingin dengan tekanan maksimum. Maka angin bertiup dari Asia menuju Australia. Karena angin melewati khatulistiwa, arah angin dibelokkan ke kiri. Pada periode ini Indonesia mengalami musim hujan, karena adanya massa uap air yang dibawa oleh angin saat melalui lautan luas di bagian utara, yaitu Samudra Pasifik dan Luat China Selatan (Gambar 17).

\section{Angin Muson Timur}

Angin Muson Timur bertiup pada April-Oktober di Indonesia. Saat matahari berada di belahan bumi utara, Australia mengalami musim dingin dengan tekanan maksimum, sedangkan di Asia lebih panas dengan tekanan minimun. Maka angin bertiup dari Australia menuju Asia. Karena angin melewati khatulistiwa maka angin dibelokkan ke arah kanan (Gambar 18). Pada periode ini, Indonesia akan mengalami musim kemarau, karena angin melalui gurun pasir di Australia Utara dan melewati lautan sempit. 
Angin muson barat berpengaruh di Laut Jawa, sebab angin langsung dari Laut Cina Selatan dan di garis khatulistiwa berbelok ke kiri, sehingga menimbulkan gelombang besar. Sementara itu, angin muson timur relatif tidak berngaruh, sebab sebelum sampai Laut Jawa, angin telah melewati Kepulauan Nusatenggara, Pulau Bali dan Pulau Jawa sehingga energinya sudah banyak berkurang. Jadi angin muson barat sangat berperan di Laut Jawa, khususnya di Muara Sungai Bodri.

Penampakan pada citra dari tahun 1972 sampai 2017 selain ada peningkatan suplai material sungai, gelombang laut juga membesar terutama angin barat. Membesarnya gelombang laut ini mungkin terkait dengan pemanasan global (global warming), yaitu fenomena meningkatnya suhu udara rata-rata di dekat permukaan bumi selama satu hingga dua abad terakhir (Mann dan Selin, 2020). Salah satu akibat pemanasan global adalah naiknya permukaan laut, yang menyebabkan gelombang laut membesar. Berdasarkan data di atas, mulai tahun 1992 sudah terlihat adanya gejala pemanasan global di daerah ini.

Meningkatnya gelombang di Laut Jawa, dan Muara Sungai Bodri semakin menjorok ke laut serta berarah ke utara. Sebagai akibatnya, gelombang laut berasal dari barat dialihkan arahnya oleh tubuh delta ke baratlaut, sejajar dengan pantai barat, dan membentuk arus sepanjang pesisir (longshore current). Arus ini cukup kuat, yang menyebabkan pantai barat bersih dan lurus, serta sangat bagus untuk pariwisata. Sungai-sungai yang bermuara di pantai barat tidak membentuk delta (kalau terbentuk kecil), karena arusnya deras. Oleh karena itu, material yang dibawa oleh sungai disebarkan ke kiri dan ke kanan di sepanjang pantai (Gambar 19). Sementara itu, di pantai timur yang arusnya lemah terbentuk endapan pantai luas, dan delta Cangkring tumbuh dengan baik.

Dataran Kendal merupakan daerah vital untuk transportasi darat di jalur utara Jawa. Adanya arus sepanjang pesisir (longshore current) di pantai barat, dan arus ini menabrak Pantai Jawa di sebelah barat Sidorejo. Pada citra spot, di sepanjang pantai ini terdapat penampakan jalur kereta api JakartaSemarang-Surabaya (Gambar 20). Jalur kereta api ini merupakan transportasi darat utama, namun jalur rel ini telah mengalami perpindahan, yang disebabkan oleh kondisi pantai. Interpretasi citra landsat 1992, 2001 dan 2017 posisi pantai bergeser ke arah daratan (Gambar 20), yang mengidikasikan daerah ini telah mengalami abrasi. Berdasarkan posisi rel kereta api dan perkembangan pantai, daerah ini perlu penangan dengan teknologi, mengingat jalur kereta api ini sangat penting.
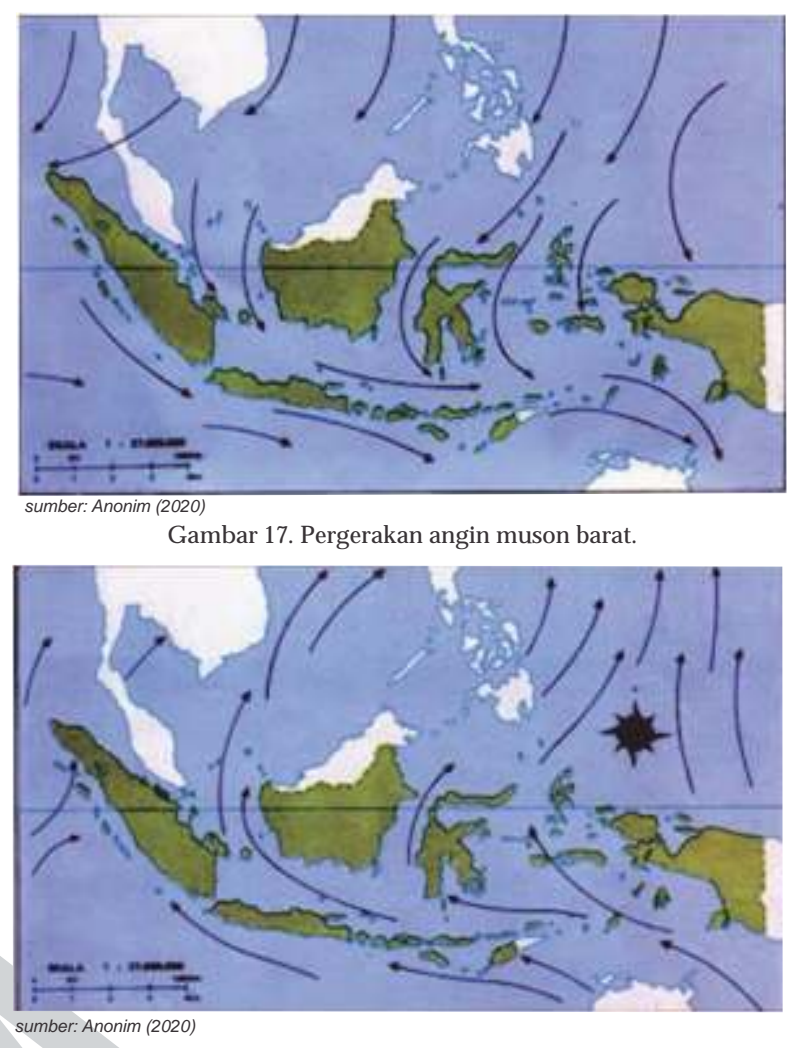

G ambar 18. Pergerakan angin muson timur.

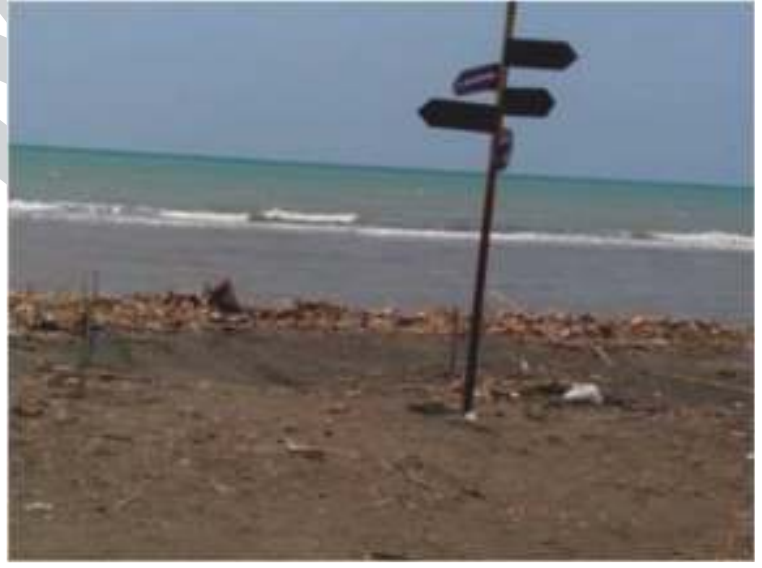

Gambar 19. Foto material yang dibawa sungai disebarkan ke kiri dan ke kanan sepanjang pantai barat (kemungkinan dibawa oleh Sungai Damar atau Sungai Blukar yang bagian hulunya banyak penambangan sirtu). Pantai ini sebelumnyasebagai salah satu destinasi wisata.

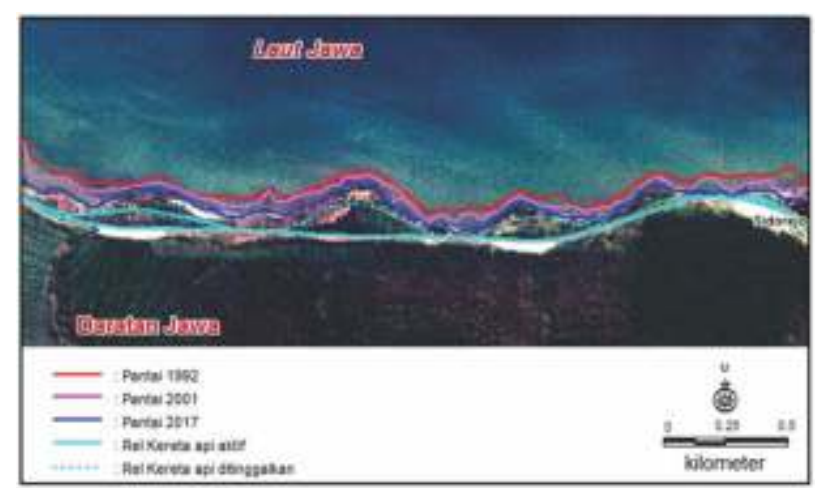

G ambar 20. Penampakan rel kereta api pada citra SPOT, dan garis pantai diinterpretasi padacitra Landsat 1992, 2001, dan 2017. 


\section{KESIMPULAN}

Muara Sungai Bodri sejak 1972 sampai 2017 telah mengalami tiga kali perpindahan. Pada tahun 1972, energi laut masih kecil sehingga Sungai Bodri dan Sungai Keceng, yang masing-masing membentuk delta cuspate, dan di pantai timur terjadi penambahan material secara signifikan. Pada tahun 1992, Sungai Keceng tidak aktif sehingga semua material masuk ke Muara Sungai Bodri, yang membuat alirannya berbelok-belok (meander), dan membentuk delta cuspate, namun gelombang laut naik, yang mengakibatkan suspended material di muara sungai tersebar ke timur dan ke utara, dan pantai timur terabrasi kuat. Pada tahun 2001, Sungai Bodri bagian muara berbelok ke baratdaya, menjorok ke laut, dan membentuk delta kerucut. Pantai barat terlihat lurus, sementara pantai timur bagian utara terabrasi, dan material hasil abrasi diendapkan sebagai tanggul, dan pantai di selatannya mengalami abrasi kecil. Penampakan citra Landsat DCM pada tahun 2017, Sungai Bodri berbelok ke utara, menjorok jauh ke laut, dan membentuk delta kerucut. Pantai barat terlihat lurus, sungai-sungai yang bermuara di pantai ini membentuk delta kecil, sementara pantai timur bagian utara terabrasi, dan punggungan yang terbentuk sebelumnya tergeser ke arah selatan dan mengecil. Di Tajung Siwalan telah dibuat suatu bangunan untuk menahaan suspended material agar tidak mengganggu Pelabuhan Merbuh dan tidak ke Semarang. Delta Cangkring sejak tahun 1972 sampai tahun 2017 terus berkembang. Perubahan Muara Badri disebabkan oleh kondisi DAS Bodri Hulu yang tersusun oleh batuan mudah tererosi, curah hujan tinggi dan dibantu oleh penambahan lahan terbuka yang diakibatkan aktifitas manusia; dan energi laut dipengaruhi oleh gelombang laut barat, yang sejak tahun 1992 terus mengalami peningkatan dan mungkin disebabkan oleh pemanasan global. Citra Landsat yang terdiri atas beberapa generasi sangat efektif digunakan untuk memonitoring perubahan Muara Bodri.

\section{UCAPAN TERIMAKASIH}

Penulis mengucapkan terimakasih sebesar-besarnya kepada Sonny Mawardi ST, MT yang telah berdiskusi pengolahan citra. Penulis juga mengucapkan terima kasih kepada Kepala Pusat Survei Geologi yang telah mengijinkan tulisan ini diterbitkan.

\section{ACUAN}

Anonim, 2020. Angin Muson: Pengertian, Proses dan Dampaknya. https://ilmugeografi.com/fenomena-alam/anginmuson.

Bird, E.C.F. and Ongkosongo, O.S.R., 1980. Environment Changes on the Coasts of Indonesia. United Nation University, Tokyo, Japan. 55pp.

BPD Temanggung, 2020. Geografi Kabupaten Temanggung. https://bpbd. temanggungkab.go.id.

Condon, W.H., Pardyanto, L., Ketner, K.B., Amin, T.C., Gafour, S., dan Samodra, H., 1999. Peta Geologi Lembar Banjarnegara dan Pekalongan, Skala 1:100.000. Pusat Penelitian dan Pengembangan Geologi, Bandung. Edisi ke2.

Gischa, S., 2020. Angin Muson Asia-Australia: Proses dan Sistemnya. https://www.kompas.com/skola.

Gupta, R.P., 2018. Remote Sensing Geology. Springer, Gemany, Third Edition, 428pp.

Lumbanbatu, U.M., 2009. Perkembangan Dataran Pantai (Costal Plain) Daerah Kendal, Provinsi Jawa Tengah. Jurnal Geologi dan Sumberdaya Mineral, 19(4): 225-237.

Mann, M.E. and Selin, H., 2020. Global Warming. https://www.britannica.com/science.

Poedjoprajitno, S., Mochtar, H., dan Hidayat, T., 2009. Perubahan Lingkungan Pengendapan Hubungannya dengan Tektonik Kuarter. Jurnal Geologi dan Sumberdaya Mineral, 19(2): 107-116.

Reineck, H.E. and Sigh, I.,B., 1973. Depositional Sedimentary Environments. New York Springer-Verlag. 301 pp.

Sanjoto, T.B., Juhadi, and Nugraha, S.B., 2019. Comparison of Delta Model in the North Coast of Central Java using Remote Sensing Techniques (Case Study in Comal, Bodri and Wulan Deltas). IOP Conference Sries:Earth and Envirenonmental Science 243 (2019) 012030. doi:10.1088/1755-1315/243/1/012030, hal. 1-10.

Seksi Kartografi, 1976. Peta Topografi Lembar Semarang dan Magelang, Skala 1:100.000. Direktorat Geologi, Bandung. 
Setiyono, H., 1996. Kamus Oseanografi. Gadjah Mada University Press, Yogakarta. 200 h.

Sulastya Putra, P. dan Praptisih, 2017. Re-Interpretasi Formasi Kerek di Daerah Klantung, Kendal, Berdasarkan Data Stratigrafi dan Foraminifera. Jurnal Geologi dan Sumberdaya Mineral, 18(2): 77-88.

Thanden, R.E., Sumadirdja, H., Richarrds, P.W., Sutisna, K., dan Amin, T.C., 1996. Peta Geologi Lembar Semarang dan Magelang, Skala 1:100.000. Pusat Penelitian dan Pengembangan Geologi, Bandung.

Wikipedia, 2020. Geografi Kabupaten Kendal. https://wikipedia.org/wiki/Kabupaten Kendal. 